\title{
READINESS OF THE DIGITAL INFRASTRUCTURE OF HIGHER EDUCATIONAL INSTITUTIONS IN UKRAINE FOR MASS DISTANCE LEARNING
}

\section{S. Grynyuk, M. Zheludenko}

National Aviation University

ORCID: 0000-0002-8019-759X; 0000-0003-2992-9481

\section{Zaytseva}

Kyiv National University of Trade and Economics

ORCID: 0000-0001-6556-0779

Purpose. Digitalization of higher education is a long-term trend that has gained a new impetus for further development due to the forced transition to distance learning during the pandemic COVID-19. The article analyzes the impact of digital transformation on the educational process in higher education institutions via teachers' and students' perception; explores the experience of mass distance learning provision in Ukraine's higher education system due to COVID-19. Methodology. The research study is based on the survey results conducted by the authors in NovemberDecember 2020 among teachers and students of sixty-five Ukrainian institutions of higher education. The authors have also explored the current state of the educational process provision in the sector of higher education in Ukraine, the EU and the world under the conditions of the pandemic; have identified problem areas in the work of higher education institutions during quarantine and social isolation conditions, as well as challenges in each structural integral. Results. The authors have specified the transformational changes experienced by the global higher education system under the impact of the pandemic, which bring to higher education institutions a huge number of serious challenges and will significantly change the global higher education system in the future. Originality. The paper investigates students' attitudes towards distance learning as a three-level unity with emotional, cognitive and behavioral aspects and draws a general conclusion that, in general, distance learning is both a field of opportunity and a possible source of individual and institutional risks. Practical value. The article determines the directions of e-learning in the entire system of distance learning in the national system of higher education in the pandemic and after it.

This article was prepared within the framework of the research project "Potential of higher education in conditions of the pandemic: global, European, national dimensions" of the National Research Fund of Ukraine.

Key words: higher education system, digitalization of educational environment, distance education, online education, students' attitude, online-survey, problem areas of higher education institutions.

\section{ГОТОВНІСТЬ ЦИФРОВОЇ ІНФРАСТРУКТУРИ ЗВО УКРАЇНИ ДО МАСОВОГО ДИСТАНЦИЙНОГО НАВЧАННЯ}

\section{С. Гринюк, М. Желуденко}

Національний авіаційний університет

ORCID: 0000-0002-8019-759X; 0000-0003-2992-9481

\section{I. Зайцева}

Київський національний торговельно-економічний університет

\section{ORCID: 0000-0001-6556-0779}

Цифровізація вищої освіти - довгострокова тенденція, що отримала новий імпульс для подальшого розвитку у зв'язку з вимушеним переходом на дистанційне навчання під час пандемії COVID-19. Мета статті - проаналізувати вплив цифрової трансформації на освітній процес у закладах вищої освіти очима викладачів і студентів, дослідити досвід масового застосування дистанційного навчання в системі вищої освіти України у зв'язку 3 COVID-19 і визначити напрями розвитку електронного навчання в національній системі вищої освіти в умовах пандемії і після неї. Автори також досліджують актуальний стан забезпечення освітнього процесу у галузі вищої освіти України, СС та світу в умовах пандемії, виділяють проблемні зони закладів вищої освіти в умовах карантину і соціальної ізоляції, а також виклики в кожному структурному інтегралі. Авторами також конкретизуються трансформаційні зміни, яких зазнала світова система вищої освіти під впливом пандемії, та які несуть закладам вищої освіти безліч серйозних викликів і суттєво змінять глобальну систему вищої освіти в майбутньому. Окрім цього, у статті досліджується ставлення студентів до дистанційного навчання як трирівнева єдність 3 емоційним, когнітивним і поведінковим аспектами та робиться загальний висновок щодо того, що, у цілому, дистанційне навчання є як полем можливостей, так і можливим джерелом індивідуальних і інституціональних ризиків. Проведене наукове дослідження грунтується на результатах опитування, проведеного авторами у листопаді-грудні 2020 року серед викладачів і студентів шістдесяти п’яти українських закладів вищої освіти. Стаття підготовлена у рамках дослідницького проекту «Потенціал вищої освіти в умовах пандемії: глобальні, європейські, національні виміри» Національного фонду досліджень України (реєстраційний номер 2020.01/0172).

Ключові слова: система вищої освіти, цифровізація освітнього середовища, дистанційна освіта, онлайносвіта, відношення студентів, онлайн-опитування, проблемні зони закладів вищої освіти.

STATING A PROBLEM. The article "Readiness of the digital infrastructure of higher educational institutions in Ukraine for mass distance learning" is a part of a fundamental team work of the scholars, who due to the NRFU competition "Science for the safety of human and society" are working on the project "The 
potential of higher education plagued by a pan-demic: global, European, national dimensions" (Project registration number: 2020.01/0172). The National Research Fund of Ukraine provides financial support for the project from the state budget. The competition was initiated by the Ministry of Education and Science of Ukraine and The National Research Fund of Ukraine in May 2020, aimed at supporting the best research projects due to human security issues, in particular the safety of human under the conditions of COVID-19 pandemic.

Today the world in general and Ukraine in particular are facing the most serious challenge of the last few decades. The global spread of coronavirus infection (COVID-19) has fundamentally changed the way of life of the world community, taught to live in a new reality and adapt to new social standards in the shortest possible time.

All sectors of the world economy have suffered the destructive impact of the pandemic. For the global higher education system, this situation has become a real stress test. Most countries of the world were not prepared for such developments, their practical measures were formed ad hoc. Consequently, at the beginning of April 2020, 170 countries closed their institutions of higher education; about 1.7 billion students and pupils could not attend universities and schools $-90 \%$ of the total population. The imposed quarantine measures led to the transition of educational institutions to a distance learning format for which the actors of the educational process were not fully prepared; therefore, there were serious obstacles to implement the model the universities had been working for centuries. On the whole, localization and social isolation measures have led to upheavals that the higher education system has not experienced since World War II.

Thus, there is no doubt that the spring of 2020 was a moment of rethinking the usual ideas and approaches in the education system and defined a number of new requirements for the effective provision of the educational process in a crisis situation.

The above-mentioned aspects have actualized the need of scientific comprehension of the problem. Thus, the research of the scientific project executors "The Potential of Higher Education in the Pandemic: Global, European, National Dimensions" is directed to solve these issues.

Analysis of the research on the implementation of distance learning in the COVID-19 pandemic in Ukraine, the EU, and the world showed that since the COVID-19 outbreak mass transition to distance education involving the use of e-learning tools in the online environment is being realized in extreme conditions to ensure continuity of the educational process.

A comprehensive theoretical study of the current state of the educational process provision in the sector of higher education in Ukraine, the EU and the world under the pandemic COVID-19 has revealed the following aspects.

The pandemic has affected the habitual modes of life of students, their families, teachers; has caused far- reaching economic and social consequences; has sharpened a package of socio-economic issues, they are as follows:

- equality of access to study (different levels of provision of families with the means for distance learning and unequal access to quality Internet);

- provision of educational services to higher education students with special educational needs;

- other socio-economic problems, predetermined by the pandemic.

The transformational changes, the global higher education system has undergone under the influence of the pandemic, bring a great number of serious challenges to higher education institutions and will significantly change the global higher education system in the future $[1 ; 2 ; 3 ; 4 ; 5]$.

In the sector of higher education, the world's governments faced challenges that required a fairly rapid response and management decisions at the national level. These included [6]:

- the need to develop legislation and guidelines for the organization of online studies and entrance or graduation examinations;

- providing advice and financial assistance to the institutions of higher education ensuring online learning;

- developing strategies and making timely decisions for providing assistance to international students who are in the country during the pandemic;

-developing additional legislation/regulations that allow international students to travel for studying.

Among the main tasks that the national institutions of higher education had to deal with during the first months of the COVID coronavirus infection outbreak were [7]:

- slowing the pandemic, keeping students and staff healthy;

- preserving the quality and accessibility of the educational and scientific process in the institutions of higher education;

- reducing costs and seeking new resources. The risks for higher education institutions under such conditions are considerable: their future - the quality of education, their reputation, their financial stability, the very existence of many of them - depends on how quickly and how well they can change.

Analysis of the educational process provision in Ukraine's higher education sector in the conditions of COVID-19 pandemic has also allowed to systematize the problem areas of higher education institutions work in quarantine and social isolation conditions (Table 1) $[8,9]$.

The Ukrainian government responded quickly and adequately enough to the new challenges, it implemented the measures necessary to ensure the continuity of the educational process [10]. For the practice of foreign countries, in Ukraine educational institutions were also temporarily closed, academic years 20192020 and 2020-2021 were completed in distance mode, which appeared a challenge for the domestic education system. 
Table 1. Problem Areas of Higher Education Institutions in Quarantine and Social Isolation Conditions

\begin{tabular}{|c|c|}
\hline $\begin{array}{l}\text { Problem area of the higher education } \\
\text { institutions work [7] }\end{array}$ & Challenges \\
\hline Legal aspects & $\begin{array}{l}\text { The necessity of adopting local normative acts and amending the current } \\
\text { federal ones. }\end{array}$ \\
\hline Digital infrastructure & $\begin{array}{l}\text { Lack of sufficient infrastructure and software even in top institutions to } \\
\text { shift to a full-distance mode. }\end{array}$ \\
\hline Teaching and working with students & $\begin{array}{l}\text { Risks of decline in the quality of higher education. } \\
\text { The need for accelerated retraining of the academic staff. } \\
\text { Massive transition to distance learning mode. } \\
\text { Unpreparedness of different target groups for the survey. }\end{array}$ \\
\hline Students' admission & $\begin{array}{l}\text { Questions of timing, procedures, and comprehensive solution for all } \\
\text { educational levels. }\end{array}$ \\
\hline Conducting a research & $\begin{array}{l}\text { Hardships in access to laboratories, limitation regarding off-line scientific } \\
\text { communication, risks of reduced research and development spending both } \\
\text { at the state level and the businesses that are incurring unpredictable costs } \\
\text { due to the pandemic. }\end{array}$ \\
\hline Administrative work & Transferring most employees to a remote mode of work. \\
\hline Campus economics & Financial losses of universities from campus closures. \\
\hline Personnel policy & $\begin{array}{l}\text { Review of motivation models in regard with the transition to the distance } \\
\text { mode of work. } \\
\text { Staff motivation for quality work in distance mode. } \\
\text { Psychological state of staff in a sudden change of the work mode. }\end{array}$ \\
\hline Safety and Security & Comprehensive issues regarding preventive measures. \\
\hline $\begin{array}{l}\text { Employment of graduates in compa- } \\
\text { nies. }\end{array}$ & Potential delays in final exams. \\
\hline Internationalization and mobility & $\begin{array}{l}\text { Risks of university financial losses due to the restricted mobility. } \\
\text { Revision of university event schedules, rescheduling of work in accord- } \\
\text { ance with these events. }\end{array}$ \\
\hline $\begin{array}{l}\text { Additional expenditures of universi- } \\
\text { ties }\end{array}$ & $\begin{array}{l}\text { Additional expenditures for the adaptation of information systems and } \\
\text { infrastructure. } \\
\text { Sanitation and security costs. } \\
\text { Reimbursements for contracts with foreign staff and searchers in case of } \\
\text { online work impossibility. } \\
\text { Additional expenses for material support to students. }\end{array}$ \\
\hline
\end{tabular}

During the long quarantine, educational materials in digital format and online resources for distance learning became available on the Internet. Also the Ministry of Education took into account the factor of absence of home computers with Internet access in a part of the population of our country, especially in low-income families and rural areas. The Ministry held negotiations with the management of leading educational online platforms, which resulted in the availability of educational content for the general educational public.

Among the partner sites that provided video content for broadcasts are the BeSmart platform (https://besmart.study); EdEra online education studio (https://www.ed-era.com); Prometheus (https://prometheus.org.ua); iLearn (https://ilearn.org.ua), a platform of free online courses; and so on [11].

The aim of the article is to analyze the impact of digital transformation on the educational process in universities through the teachers' and students' eyes. The analysis is based on the results of a survey conducted by the authors in 2020 among teachers and students of 65 Ukrainian universities.

MATERIAL AND STUDY RESULTS. Most higher education institutions in Ukraine were not fully ready to implement mass distance learning, although regulations on distance learning in Ukraine were approved by the Ministry of Education and Science of Ukraine in 2013.

The transition to distance learning is based on the key elements of the digitalization process: the use of digital infrastructure, the possession of specialized devices, the implementation of exchanges and knowledge transfer via the Internet, and the delocalization of learning [12]. Digitalization of the educational environment, therefore, should be understood as a process of multicomponent technologization of educational practices, affecting all actors of the academic process and including the digitization of educational content, the implementation of a digital management system and digital procedures for monitoring students' knowledge, the transition to online communication between teachers and students, as well as between teachers themselves, between teachers and the academic management. At the core of such a system is the digitalization of learning: the transformation of the way the knowledge and the professional training are acquired, developed, and recognized through the use of digital technologies [13].

Digitalization of the educational environment is accelerated not only by the development of information technology, but also by the intensive implementation of market relations in the system of higher education [14]. It is also important to understand that the digital educa- 
tional space destroys the boundaries of national educational systems, depersonalizing national specificity and educational priorities, thus stimulating the formation of the institute of global education with its own laws and structures of functioning, and with it forming a global student with a universal system of values and competences. The globalization of education has undeniable benefits, but its processes also have dysfunctional consequences [15]. Like any innovation, the digital educational environment produces a set of risks [16]. These risks and their perception by students were considered by us during the empirical study of the practices of distance education implementation in 65 universities in Ukraine.

To achieve the objectives of the research we have chosen a mixed multi-phased research design implying the use of quantitative and qualitative research methods. The study was characterized by four sequential phases: questionnaire compilation, data collection, data analysis, and knowledge generation. The given research was conducted in compliance with the ethical research standards. Prior to the survey, all the participants were informed about the goals of the research and assured that their answers would remain confidential and would be used for the research purposes only.

The study was carried out by a survey organizer National Aviation University - within the framework of the research project "Potential of higher education in conditions of the pandemic: global, European, national dimensions" of the National Research Fund of Ukraine. The study participants comprised both representatives of teaching staff and students of higher education institutions of Ukraine. The field stage embraced November 20 - December 15, 2020.

The total number of responses was 882 from 65 Ukrainian higher education institutions. $78.5 \%$ of the respondents were students and $21.5 \%$ of the respondents were teachers. $86.8 \%$ of them were female and $13.2 \%$ were male. Age under 20 was $59 \%$ of the respondents, 21 to 30 was $19 \%$ of the respondents, 31 to $40-7.6 \%$ of the respondents, 41 to 50 was $7.6 \%$ of the respondents, 51 to 60 was $5.3 \%$ of the respondents, over 60 was $1.5 \%$ of the respondents.

The most active in the survey were teachers and students of the National Aviation University, Kyiv National University of Trade and Economics, Flight Academy of the National Aviation University, Lesya Ukrainka Volyn National University, National Technical University of Ukraine "Igor Sikorsky Kyiv Polytechnic Institute", Odesa State Agrarian University, Borys Grinchenko Kyiv University, Rivne State University of the Humanities, Ivan Ziaziun Institute of Pedagogical Education and Adult Education of the National Academy of Pedagogical Sciences of Ukraine, National University "Odesa Law Academy", Taras Shevchenko National University of Kyiv, which amounted to $39.1 \%$ of all respondents. Since it was impossible to draw conclusions for each region within the framework of this study, the analysis was carried out according to the average indicators of the whole sample.

The current study seeks to study only the technical aspect of forced distance learning provision in Ukraine's higher education system. By and large, only 2 questions out of 30 from a closed-format questionnaire were presented in this article and two basic criteria were taken as such to examine the university digital readiness to mass distance learning implementation:

- Availability of software and sufficient equipment to organize a teacher's workplace in education institutions.

- Availability of digital educational resources in education institutions.

An analysis of the survey participants' responses showed that the mass transition to distance instruction in connection with quarantine measures has become a new reality for most universities. Accordingly, the opinions of the survey participants about the availability of software and sufficient equipment for the organization of a teacher's workplace in higher education institutions showed that awareness of the need and the actual state of affairs in universities on this criterion are different. $59.4 \%$ of the respondents who took part in the survey actually indicated the imbalance between the necessary conditions, which, in their opinion, should be created in universities to implement distance education, and the actual state of affairs in universities. $50.1 \%$ of the respondents indicated partial realization, $9.3 \%$ indicated no realization (Figure 1).

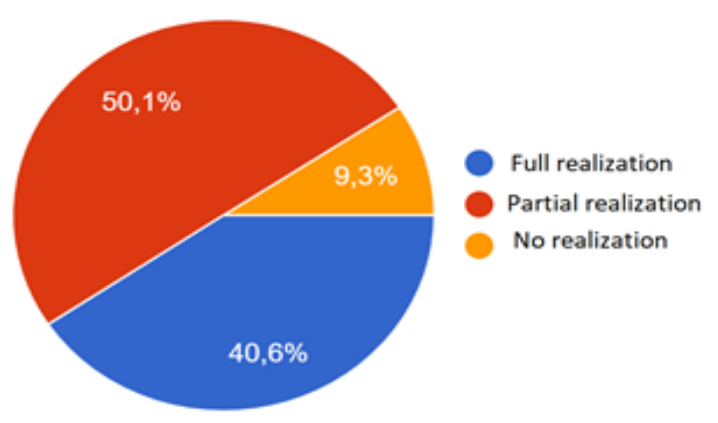

Figure 1 - Availability of software and sufficient equipment to organize a teacher's workplace in educational institutions

The following were identified as the main problems:

$\checkmark \quad$ Lack of stable and sustainable connection to the Internet (and the paramount importance of this condition is quite natural);

$\checkmark \quad$ Lack of an equipped workplace for the teacher (laptop, computer, tablet, online whiteboard with the possibility of real-time collaboration. It can be assumed that some teachers in the conditions of self-isolation rely on their own home technical resources);

$\checkmark \quad$ Insufficient measures of methodological support for teachers in distance learning.

The effectiveness of distance learning in selfisolation is largely due to the organization of the university administration, psychological readiness and motivation of the teaching staff, students and parents. In response to the difficulties of transition to the new mode of work and study, the support system grew rather quickly. Virtually all universities sent faculty members methodological recommendations. The universities created special websites or sections of official websites 
to inform and help teachers in the current situation. They also launched programs of methodological support for teachers. The most active teachers shared their experience, knowledge of resources through social networks, and held special webinars.

One of the determining conditions of teachers' readiness is the availability of a system of methodological support. $47.5 \%$ of the respondents were aware of this need. Only $45.7 \%$ of teachers received such support in the form of master classes, webinars, consultations, etc. (Figure 2). According to the interviewed teachers, today the educational organization does not always have the opportunity to provide fullfledged work and support the teacher in implementing quality distance learning in the conditions of selfisolation.

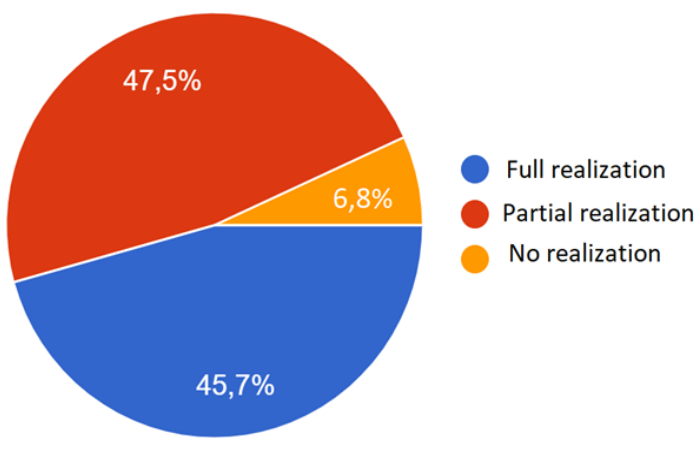

Figure 2 - Availability of digital educational resources in education institutions

In addition, the conducted study has also allowed us to reveal the online resources that are used in the organization of distance learning, preparation for distance learning classes, formation and performance of homework, control and assessment materials. Thus, the majority of the students and teachers use the resources from such online educational platforms as Zoom $(88.3 \%)$ and Classroom (85.3\%). This fact proves that the innovative approach of Zoom and Classroom technology enhances positive learning outcomes for students. Other respondents use resources from such online educational platforms and tools as: YouTube (49.5\%), Moodle (47.3\%), Teams (35.7\%), Skype (32.9\%), Microsoft (12\%), Coursera (7.7\%), Kahoot (7.6\%), Education (7\%), etc.

CONCLUSION. The situation with the outbreakof the COVID-19 has clearly demonstrated that countries and universities are facing the same challenges, but, are responding at different speeds. The higher education community is now moving from a crisis management situation to a more long-term planning that can ensure the continuity of the educational process. Many of the solutions implemented during the crisis showed their usefulness and will probably continue, but in order to continue offering quality education in the new academic years, careful planning should be done, as new challenges emerge.

The study results of "The readiness of Ukraine's digital infrastructure to mass distance learning", revealed that, despite the difficulties, the Ukraine's higher education system is ensuring the continuity of the educational process in the conditions of the COVID-19 pandemic.

The current state of the educational process provision in the sector of higher education in Ukraine, the EU and the world under the conditions of the pandemic has shown the problem areas of higher education institutions in quarantine and social isolation conditions, as well as challenges in each structural integral.

The revealed transformational changes experienced by the global higher education system under the impact of the pandemic have brought to the higher education institutions a huge number of serious challenges and will significantly change the global higher education system in the future.

Still, the analysis of the survey results has allowed us to formulate the positive characteristics of distance learning in the pandemic:

1) Popular digital tools (Zoom, YouTube, Google Classroom, Moodle) are the basis of education.

2) The overall statistics on the number of users of the most popular digital tools is quite compelling: the number of Zoom users in March 2020 was over 200 million users per day, and the number of Google Classroom downloads as of March 30, 2020 was over 50 million.

The authors have come to a conclusion that the process of transition to distance learning should be considered comprehensively, e.d. as a phenomenon of information-technical, psychosocial nature. In practice, this can be achieved by creating a single digital market for services and knowledge, which will help adapting to the changes associated with digital transformation.

The students' attitude towards distance learning is seen as a three-level unity with emotional, cognitive and behavioral aspects.

It is worth to mention that despite the difficulties in the adaptation to a completely different methodology for teaching, the higher education sector demonstrated reactivity in order to find solutions to the challenge raised by the pandemic, and of continuing teaching and learning. The most sensitive point was to provide relevant information to students and applicants regarding the situation in higher education. The most successful countries have established funds and student support hotlines. It is therefore concluded in the article that distance learning is both the field of opportunities and possible source of individual and institutional risks.

The conducted research does not examine all aspects of the stated problem. A number of aspects are still awaiting for being precisely examined, for instance, the the quality of learning that is affected by the shift from face-to-face instruction to online instruction.

\section{REFERENCES}

1. United Nations Development Programme. COVID-19 and human development: Assessing the crisis, envisioning the recovery. 2020. Human Development Perspectives, 2020, New York: UNDP. URL: http://hdr.undp.org/en/hdp-covid

2. Michelle Kaffenberger (2020), Modeling the long-run learning impact of the COVID-19 learning shock: Actions to (more than) mitigate loss. RISE In- 
sight Series. 2020/017, 4 June 2020. URL: http://doi.org/10.35489/BSG-RISE-RI_2020/017

3. World Bank. COVID-19 Could Lead to Permanent Loss in Learning and Trillions of Dollars in Lost Earnings. 18 June 2020. URL: https://www.worldbank.org/en/news/pressrelease/2020/06/18/

4. International Association of Universities, Global Survey Report: The Impact of COVID-19 on higher education around the world. 2020. URL: https://www.iau-

aiu.net/IMG/pdf/iau_covid19_and_he_survey_report_fi nal_may_2020.pdf.

5. Maggioncalda Jeff. The Digital Transformation of Higher Education: COVID-19 and Beyond. YouTube: channel IITO UNESCO. URL: https://www.youtube.com/watch?v=qTJXAElBSks

6. COVID-19: Higher Education challenges and responses. 2020. URL: https://iau-aiu.net/Covid-19Higher-Education-challenges-and-responses

7. Grynyuk, S., Zasluzhena, A., Zaytseva, I. and Liahina, I. (2020), Higher education of Ukraine plagued by the Covid-19 pandemic. In: ICERI 2020, 13th International Conference of Education, Research and Innovation. Valencia, Spain, 9-10 November 2020. ISERI. 10.21125/iceri.2020.0667

8. Grynyuk, S., Kovtun, O. (2021), Osvitnyi protses u galuzi vushoyi osvitu Ukrainy, ES ta svity v imovah pandemii COVID-19. Vuscha osvita $v$ umovah pandemii. 2021. K.: Talkom. P. 89-103. (Humanitarnuy dusryrs syspilstva ruzuky)

9. Kovtun, O., Melnyk, N., Grynyuk, S. and Rohalska-Yablonska, I. (2021), General and communication impacts of the COVID-19 pandemic on higher education: Global and Ukrainian dimensions. In: INTED 2021, 15th International Technology, Education and Development Conference. Spain, 8-9 March, 2021. IATED. doi: 10.21125/inted.2021.1925.

10. Sackstein, S., Coleman, E. Ndobe, T. (2019), Lecturers' perceptions of learning management systems within a previously disadvantaged university. In Opening Up Education for Inclusivity Across Digital Economies and Societies. 2019. P. 1-28.

11. Pidchasov, E. V. (2016), Psychologichni osobluvosti pobudovy osvitnyogo procesu iz zastosyvannyam dystantsiynyh osvitnih tehnologiy. 2016. URL: http://2016.moodlemoot.in.ua/ course/view.php?id=110

12. Osipov, G. V., Kvilitskiy, S. V. (2018), Tsifrovizatsiya obstchestvennoi zhizni I novie zadachi sotsialnoy nauki. Humanitarnuye, sotsialnoekonomitsheskiye I obshestvennue nauki. №. 7. DOI: 10.23672/SAE.2018.2018.15791

13. Digital Education Action Plan (2021-2027). Resetting education and training for the digital age. European Commission. URL: https://ec.europa. eu/education/education-in-the-eu/digital-educationaction-plan_en

14. Tulchinskyi, G. L. (2017), Tsifrovaya transformatsia obrazovania: vyzovu vysshey shkoly. Filosofskiye nauki. 2017. № 6. P. 121-136.

15. Shafranov-Kytsev, G. F. (2017), Nekotorie tendentsiyi razvitia rosiyskogo vysshego obrazovania $\mathrm{v}$ tsifrovuyu epohu. Vesnik Tymenskogo gosudarstvennogo yniversiteta. Sotsialno-ekonomitsheskiye I pravoviye aspektu issledovaniya. 2017. V. 3. № 4. P. 818. DOI: $10.21684 / 2411-7897-2017-3-4-8-18$

16. Kravchenko, S. (2020), The birth of "normal trauma": The effect of non-linear development. 2020. № $\quad 13(2)$. P. $150-159$. https://doi.org/10.14254/2071-789X.2020/13-2/11 